\title{
A Brief History of the Princess Stock Company*
}

\author{
By J. Walter Forster
}

Mr. Forster, a native of Bedford, Iowa, received his B.F.A. and M.F.A. in Theatre Arts from Drake University in Des Moines. The following article developed as a part of a continuing research project in an American Theatre History course which Mr. Forster took while a graduate assistant at Drake. This fall, Mr. Forster will be teaching at Auburn University in Auburn, Alabama.

\section{lowa Before The Princess}

The Princess Theater and Stock Company, a legitimate theater and its production company, was located in Des Moines from 1909 to 1930 and was the most exciting, and probably the most successful, commercial theatre venture to ever be attempted in Iowa. It was exciting because for the first time in Iowa's history a concerted effort was made to bring the best possible professional theatre to Central Iowa audiences, and its innovative new theater, built in the summer of 1909 on Fourth Street, between Locust and Walnut, included some of the latest and newest ideas in theater construction and design.

Even more exciting was the Princess Stock Company, comprised of high grade professional actors from both the East and West coasts of the United States (the coasts were then, as now, the great theatre centers of this country). This company, in the years from 1909 to 1930, was instrumental in developing three of America's leading stage and screen actors: Fay Bainter and Conrad Nagel, who were with the Princess Stock Company from the fall of 1914 to the spring of 1916, and Ralph Bellamy who was producer and lead actor for the company (at that time named The Ralph Bellamy Players) for the 1926-27 season.

The Princess Theater and its company was the first pro-

- Grateful acknowledgment is made to the Historical Library and the Newspaper Department of the Department of History and Archives for their assistance in providing research materials and photos, and to Edward Conowitz for his photo reproduction. 
fessional stock company in Iowa. It was not, however, the only theater in the state. Quite the contrary, Iowa in the years before 1909, when the Princess Theater first opened, had an enormous number of theaters. For the season 1908-19, the Julius Cahn's Official Theatrical Guide (a guide for tour managers of road shows) shows Iowa as having one hundred twenty-nine theaters, opera houses, and auditoriums, each with full time management and technical staffs. ${ }^{1}$ Cahn's Guide gives no indication of the quality of shows which were done at these theaters, but it can generally be assumed that standard fare would have been road shows arranged by the Shubert Brothers' and other theatrical syndicates or by vaudeville companies. The quality of the shows was most likely not too high.

Regardless of the quality of theatre there were many in operation and a large percentage of the population was attending. The theaters were spread into every corner of the state in an evenly distributed manner, with no heavy concentration in the larger urban areas. Des Moines, with the largest population in the state $(90,000)$ could boast of only three fully operating legitimate theaters and several vaudeville houses. So this left the remainder of Iowa with the other one hundred twenty-six, many of them located in communities of no more than five or six hundred people.

With a background like this, Iowa and Des Moines were ready and more than willing to accept the Princess Theater and its Company. The people of Iowa, generally used to poor theatre, found the Princess, in this writers estimation, the most exciting and polished producing company the State had ever seen. And, if it can be said that Iowa had a "Golden Age" of theatre, it was surely in the years from 1909 to 1930 at the Princess.

\section{The New Princess Theater}

In the spring of 1909 Kip Elbert and Ralph Getchell, two of Des Moines' leading theatrical producers, entered into a financial agreement with Oscar Lofquist, a Des Moines financier, for Mr. Lofquist to build and lease to them a new theater - The Princess. Elbert \& Getchell planned to build the most elaborate and modern theater to ever be constructed in the State. For their proposed theater they expended large quanti- 
ties of money, sending producers and contractors to examine and gleen the best qualities of theaters in Chicago, New York, and Philadelphia. Also, special designers were retained to help plan the theater.

The elaborate planning that was involved and some general construction details are described by John L. Shipley, the company's press representative, in the November 1, 1909 edition of the Princess Bulletin, the official weekly publication for the Princess Stock Company.

Construction of the physical theater must have been amazing, and Shipley stated that after the plans were finalized and the foundation was layed, ". . .the first brick was set in place on July 20 [1909]. . ." and “. . .with the rapidity that comes only through the finely concerted effort of modern building forces the Princess has been finished and ready to open on November 1, [1909] the scheduled time."2 This was a brief period of time in which to build a structure the size of the Princess. The Bulletin goes on to explain, however, that during the peak period of construction as many as one hundred workmen were employed. Probably the reason for such haste in building was the lateness of opening the theater. The theater seasons began in late August and the Princess Company was losing a great deal of money by not being open and producing plays.

The Bulletin continued by describing the elegance and durability of the theater, with its white terra cotta facade fronted by a canopy of glass set in an ornamental frame, a lobby of white glass and a foyer with ornamentally grilled borders and furnishings, all of which was described by Mr. Shipley as ". . .elaborate and rich in its simplicity." ${ }^{3}$ New ideas in auditorium construction were also included in the Princess, with wider aisles, more space between rows of seats, and a less steep incline from the back of the theater to the stage. (Most theaters, at this time, were cramped, uncomfortable, and difficult to get around in.)

Of particular interest was the fact that the theater was completely fire proof. Theater fires during the fifty years prior to 1904 had been a major problem, culminating in the Iroquois Theater fire, in Chicago, of that year. One hundred forty-three 
people were lost in the disaster, and shortly after, almost all states and cities in the nation, including Des Moines, established laws and codes strictly regulating the fire proofing and construction of all new theaters. The Princess, being the first theater constructed in the city after the new codes, was reputed to have been built with all non-combustible materials. Other safety factors included: nineteen fire exits, which even today would be considered an inordinate number; and an asbestos drop, or fire curtain, which could be dropped in less than three seconds to cover the stage's proscenium opening.

As to the comfort of the patron the new theater was heated by a system of large fans which pumped outside air into a large room containing steam coils; the air was heated and then pumped into the auditorium where the temperature was ". . . regulated by automatic thermostats." And for the late summer months when the theater would normally open, the same ventilating system would be used to ". . . send cool air into the house, the room into which the outdoor air is pumped being iced." (This was obviously an early attempt at air conditioning and probably modeled after an invention by Steele Mackay who installed a cooling system when he constructed his Fifth Street Theater in New York in the 1870s.) Other comforts of the Princess included a large staff of personnel which served as: ushers, maids in the ladies' rooms, attendants in the men's rooms, concessionaires, and general lobby personnel. The theater's seats were richly upholstered and comfortably cushioned. Physically, little, if anything, was left to be desired by the patron.

The Princess Theater must have been considered a marvelous addition to the Des Moines business district for no theater had ever been constructed in the city which was as well built or modern. But the building was only the beginning. It was the audience, the actors, and the critics who exemplified the excitement that was the real Princess Theater for the next twenty-one years.

\section{The First Season (1909-10)}

The first commercial announcement for the opening of the Princess Stock Company came in October of 1909, and on Monday evening, November 1 , only hours after the final 
scaffolding had been removed from the front of the building, the Company opened its season with a production of Avery Hopwood and Channing Pollock's Clothes, a Broadway comedy of the past season. The Tuesday, November 2, edition of The Des Moines Register and Leader declared the Company “. . . A truly great success." Elbert and Getchell, the producers, were both highly praised for their contribution to Des Moines' theatre, and Frederick Sullivan, the Company's director, was acclaimed for his "directorial excellence." And, in the same review, Emma Salvatore, one of the Company's female character actors, was lauded for ". . . a strong character portrayal seldom seen in a woman." ${ }^{\text {Th }}$ The Register and Leader stated further in this same edition:

The dedication of the new Princess proved to be an event of singular brilliance. Ther(sic) is nothing lacking to add the uttermost note of felicity to the affair. The company which the youngest firm of managers [Elbert and Getchell] has painstakingly brought together is entitled to the best support Des Moines is capable of putting forth. The Princess Stock Company was the most agreeable surprise of all. It's a surprise because out here in the provinces we have fallen into the habit of not expecting to have too much for us when we wish to be entertained and it rather takes our breath away when we are gratituously given more than we thought we could ask. ${ }^{9}$

Other newspapers in Des Moines responded in a like manner. The Daily Capital referred to the Princess Theater as being, "A beautiful playhouse. .." ${ }^{10}$ and to the Company's opening as ". . . a notable event in Des Moines theatrical annals." ${ }^{\prime 11}$ Also, the Daily Capital was greatly impressed with the efficient operation of the theater, and in their November 2, 1909, review, stated:

Unlike most opening nights, not a hitch occurred to mar the felicity of the occasion. So elaborate and carefully laid were the plans of Managers Elbert and Getchell that when the new playhouse was thrown open every detail had been provided for. This was true not only of the arrangements of the theater, but of the performance as well. It moved along smoothly and evenly, and a stranger in the house would never have guessed that it was the first appearance of the new company in a new play and a new playhouse. ${ }^{12}$

Another reviewer, this time writing for the Evening Tribune, a paper that seldom took a strong interest in the city's theatrical events, seemed more interested in the magnatism 


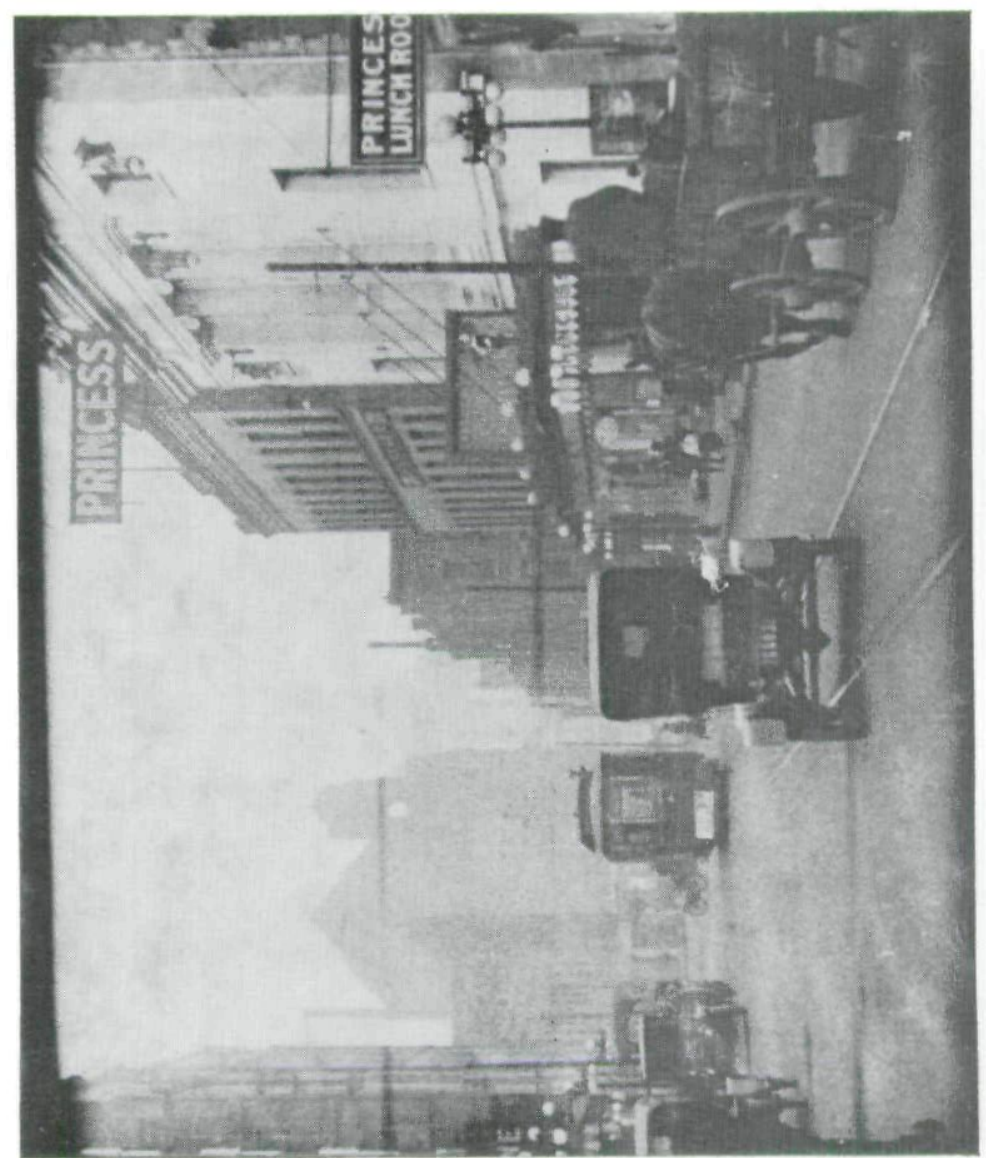

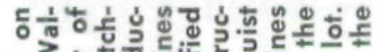

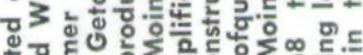
o 。ํㅡㄹ 的产 3.

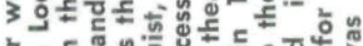

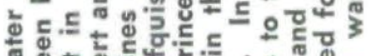
\%

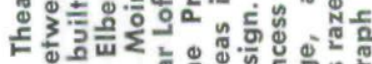

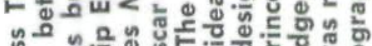

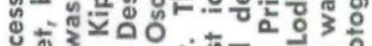

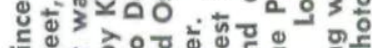

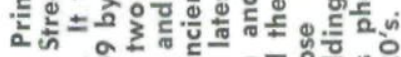
다의

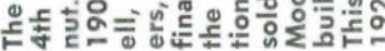


created by the opening of the theater than by the Company's production.

The brilliant lights, uniforms of attendants, the pretty entrance before a background of magnificent flowers, American beauties, chrysanthemums, carnations, which formed a setting for the pretty girl ushers, brought happy exclamations of admiration from the people who were turned away in hundreds because the seats were all gone. ${ }^{13}$

And finally, on the editorial page of The Daily News of November 2, 1909, were these comments concerning the theater building itself.

Elbert and Getchell well deserve the congratulations a gen-
erous public is showering upon them in the opening of the
Princess, their new Fourth Street opera house. If there is such
a thing as bringing New York to Des Moines in the way of
eastern ideas in opera house architecture, then the proprietors
of the Princess may feel they have accomplished just that.
A prettier, more convenient and better arranged theater will
not be found anywhere, [in the Des Moines area] and the
News predicts a generous patronage for its promoters. ${ }^{14}$

The Des Moines newspapers seemed to reflect the feelings of the general public. The audience had gotten their first glimpse of New York and Los Angeles style professional theatre and they wanted more. There was constant support for the theatre and the management of the Princess was often forced to warn the general public that ". . . many of the better seats on the ground floor have been taken by season ticket holders," and that "patrons not possessing season tickets should check with the boxoffice at least one week in advance."15

With feelings of success from their opening production the Company launched into its full season of shows, and they followed a tiresome schedule. Each week they were to present a different play with no repeats of the same play during the season (which during this first year ran from November to May). Performances were given every evening, seven nights a week, with matinees on Wednesdays, Fridays, Saturdays, Sundays and all legal holidays; this was a minimum of eleven performances a week. The work, however, didn't seem to bother the Company, as actors were much hardier then than now, and between the beginning and end of the season they presented twenty-seven plays with a total of two hundred ninetyseven performances. ${ }^{16}$ 
All of the plays produced at the Princess were full length and generally the works of leading playwrights of the day. The plays of such writers as William V. Moody, David Belasco, William C. DeMille, Rex Beach, and George Ade, all popular playwrights of that time, were regularly produced at the Princess Theater, and they were all well-produced. The management of the theater spared no expense in acquiring the best scenery, stage furnishings, properties, and costumes to present each play as elaborately as any New York production might be done.

The Company's efforts were reflected in the favorable reviews that continued in the Des Moines newspapers throughout the season, and they seemed to indicate that the Princess Stock Company was a success both artistically and financially. All was not well, however, as there was some dissatisfaction within the Company. Several of the actors left before the end of the season, and Frederick Sullivan, the Company director, did not return for the next season. There is a possibility that he was fired as contract arrangements, at this time, were generally made in the spring of the year, and if a change was made in personnel it was usually announced during the spring portion of the season. In the case of Mr. Sullivan there was no announcement. None of these problems seemed to disturb Elbert and Getchell, however, as they probably made a tidy profit during the year, and at the end of the 1909-10 season, they announced that the Princess Stock would resume production the next fall.

\section{The Second Season (1910-11)}

The Princess Stock Company reassembled in Des Moines in August and set about the task of beginning a new season. A new director, Charles Brokate, arrived from Los Angeles and immediately began rehearsals for the first production of the year, Merely Mary Ann by Israel Zangwill. Besides the new stage director there was a new musical director and several changes in the acting company, among them Robert Preston, Mabel Langdon, and A. C. Henderson, all of whom would become prominent members of the Company during the next few years.

The first production of the season, Merely Mary Ann, was 
considered a success by Des Moines' reviewers and was followed in weekly succession by more plays of the same caliber. During this season, as the first, the Company generally used only the best plays available and most generally only those plays with reasonably long Broadway runs. As during the previous season such notable playwrights as David Belasco, Winchell Smith, Clyde Fitch, George Broadhurst, and George Ade were well represented at the Princess Theater. Also, during this season, the Company produced its first and last Shakespearian production, Taming of the Shrew. Shakespeare's works met with strong disfavor among reviewers and patrons alike, both having been conditioned to the Broadway melodrama that was the popular fare of the day, and Shakespeare was never attempted again at the Princess.

From the beginning of the 1910-11 season the Company received fair to good reviews from Des Moines' papers, and all seemed to be proceeding normally. Then, on November 20, 1910, the Princess Bulletin for that week announced the midseason resignation of Charles Brokate, the Company director. The Bulletin stated that, "Mr. Brokate, dramatics director for the Princess Stock Company, has been advised by his doctor that the unseasonably cold Iowa winter has become injurious to his health, and it is suggested that he move to a warmer climate." ${ }^{" 17}$ This turn of events, surprisingly enough, was an ironic piece of luck for the Company as Elbert and Getchell were able to secure the services of Priestly Morrison, a veteran stage director who had worked extensively on the west coast. Morrison, who was at that time in semi-retirement and trying to write plays, agreed to come to Des Moines and, ". . . .accepted the challenge." 18

Morrison arrived in Des Moines during December and immediately assumed the duties of director. The season had probably been planned well in advance and Morrison made no marked changes in Company or its personnel, with the exception of Morrison's wife, Mary, a fine character actress, being included as a new member of the group. There was, however, a change in the quality of the productions as reflected in the better reviews the Company began to receive, and it is likely that this heightened quality of work was the result of Mor- 


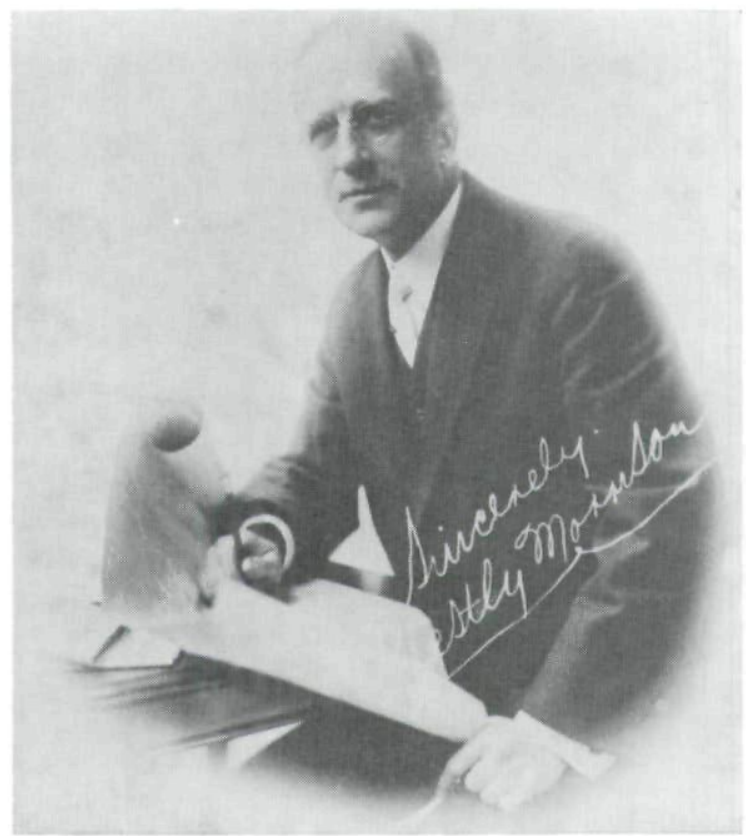

Priestly Morrison

rison's directorship. Unfortunately, it is difficult to tell exactly how the productions improved. Des Moines' reviewers were not very adept at dramatic criticism and more often than not they gave very flowery exclamations of what they saw rather than an explanation of why it might have happened. Regardless, Morrison won the favor of both public and press, and by the end of the season had firmly entrenched himself at the Princess Theater. In his seasonal farewell speech Morrison stated:

This has been a long season, and a happy one for all of us. Though I arrived here late in the season I feel that the time has not been wasted, and I now can assure [you] that next fall we will give you the best season ever. ${ }^{19}$

The Third Season (1911-12)

Morrison re-formed the Company in early August to begin preparation for the coming season. Accompanying him from California, where he lived during the summer months, were many new actors, probably recruited from the Los 
Angeles area-where he did most of his hiring-to fill the vacancies that had occurred at the end of the 1910-11 season. Most notable among the new Company members were Victor Mosher, Ralph Starr, Guy Harrington, and William J. Mack, the latter destined in later years to become the assistant dramatics director and finally replace Morrison at the Princess in 1917. Another new name that appeared on the cast list was that of Charles Hubbell, nephew to Frederick M. Hubbell and the first local actor known to be listed by name on a Princess playbill.

Morrison began the season on August 27, 1911 with a production of Thompson Buchanan's A Woman's Way. Press reaction to the play was good but not extraordinary. Public reaction was good, too, and it appears that the Company, if not an artistic success, was financially successful. One indication of this success was that as the season progressed, less and less commercial advertising appeared in the Princess Bulletin, the Company's official weekly publication, with more and more space being devoted to biographical sketches of Company members, greenroom gossip, and letters from the patrons praising the Company. To further point up the possible financial successes of the Company was an item in the Bulletin which stated that, "Mrs. Emma Salvatore has recently purchased a residence on the west side and will be holding a tea for the ladies of the Princess Company on Friday morning of this week [Oct. 8, 1911]." ${ }^{\prime 20}$ As previously mentioned, Mrs. Salvatore was a member of the Princess Company and it would appear that salaries for company members were quite high as West side residents at that time, as now, were probably the most expensive in Des Moines. Prior to this time all Company members were mentioned as living either in hotels or boarding houses. Lastly, in November of this year, Elbert and Getchell, the Company's producers, announced the opening of their new Berchel Opera House, a theater more than likely opened with profits that were being taken out of the Princess.

This financial success of the Princess seemed to stem from Morrison's ability to produce consistently high quality plays. Like his predecessors, Morrison did the best possible plays of the period, and the entire 1911-12 season was devoted to the works of William Gillette, Oscar Wilde, Paul Armstrong, 
Clyde Fitch, Haddon Chambers, and David Belasco. There were exceptions, but the bulk of the season's plays can be attributed to the works of these quality playwrights.

Des Moines newspapers were still very much impressed with the Princess Stock Company, even in their third season. Adequate reviews were still few and far between, but the papers were very generous with their feature space, and during this season the Des Moines Sunday Register initiated a weekly half page news section aptly called "Plays and Players," which was located in the "Cub and Society" supplement of the paper. Coverage of the activities at the Princess became so good, in fact, that the Company could have almost eliminated all of their commercial advertising. (They didn't, however, and the amount of feature coverage was probably and realistically in proportion to the advertising space the Company bought.) In almost every instance, and in all papers with such feature sections, the Princess Stock Company's notices and material dominated, generally with pictures of featured performers of succeeding week's performances occupying most of the space. And, in the same fashion, the Company received first position in the review columns of all Monday newspaper editions.

By the end of the season the Princess Stock Company had once more proven itself popular with both the public and press, and probably had by that time become the most important entertainment attraction in Des Moines. Under Morrison the Company seemed to flourish even more than in the past, and the 1911-12 season was one of the finest the Princess had seen. They had made the season a success, both artistically and financially, and had done so without a name star in the Company.

\section{Fourth and Fifth Seasons (1912-14)}

Little is known of the fourth and fifth seasons of the Princess as the Princess Bulletins were few and fragmentary for this period. That the Company continued with relatively high success is assumed, and the mere fact that they returned for these two seasons is enough to indicate sufficient commercial gain. Also, during the years 1912-14, Elbert and Getchell, from all indications, were investing heavily in their new Berchel Opera House and had acquired a facility for 
studios and scenery shops separate from the theaters. It is likely that the money for these new enterprises was taken from the profits of the Princess Theater.

Priestly Morrison was still the Company's director. However, several new names now appeared on the cast's lists. Among the new names to appear were Margaret Dills and Edward Woodruff, both from Los Angeles, and at this time the Company's leading lady and man. Another new name on the cast list was that of Mr. Eugene Shakespeare, a character actor of whom it was said, "In the earlier years of his career ... had the extreme good fortune of acting on the stage with Mr. Edwin Booth." ${ }^{21}$

Spot checks of reviews in the Des Moines Register and Leader, the Des Moines Capital, and the Des Moines News for the two seasons revealed that the Company was still in the good graces of local newspapers and that the quality and popularity of playwrights and plays produced were as good as the past seasons had been.

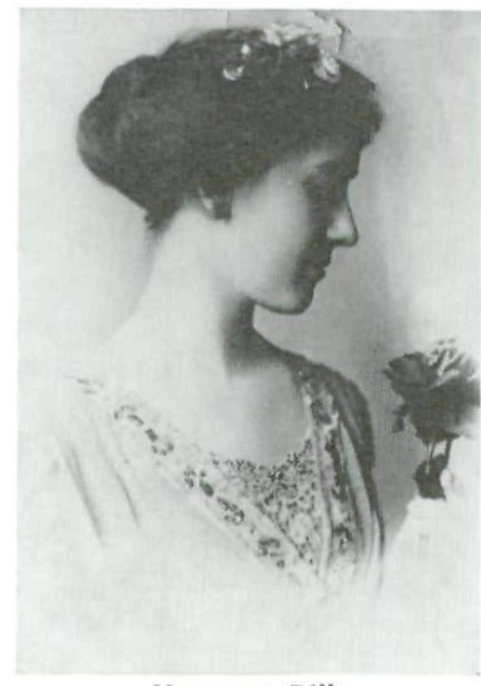

\section{Margaret Dills}

\section{The First Bainter Year (1914-15)}

In the summer of 1914 Priestly Morrison engaged Fay Bainter as the Company's leading ingenue for the 1914-15 season. Miss Bainter was by no means an amateur even though she was only twenty at the time. She had made her first stage 
appearance in Los Angeles at the age of six and had since that time appeared with many civic and professional stock companies. And, during the two previous seasons (1912-14) she had performed on Broadway in The Rose of Panama, and toured for a season with Mrs. Fiske, a famous American actress of the early Twentieth century.

Her first appearance with the Company was on August 23, 1914, in the Company's opening production of Winchell Smith's The Fortune Hunter, in which she portrayed the part of the druggist's daughter. Most of the praise from both the press and public went to the Company's leading lady and man, Margaret Dills and Edward Woodruff. Fay Bainter was, however, mentioned in several reviews, but only casually as a new face in the cast.

It wasn't until the third production of the season, The Girl and the Pennant by Rida Young, in which Miss Bainter played the part of Mona Fitzgerald, that the reviewers began to notice her. One reviewer wrote:

There is nothing in the play that requires great acting, but the Princess Company has already given sufficient proof of it's (sic.) ability to make it unnecessary to say it was well done. Miss Bainter's marked personality and excellent technic (sic.) made the role of Mona Fitzgerald all that it should be. ${ }^{22}$

This production of The Girl and the Pennant was the first real break for Fay Bainter in Des Moines, and soon the interest of local playgoers began to increase for the young ingenue.

In a review from the Des Moines Register and Leader, dated September 7, 1914, the first mention was made of Conrad Nagel, who would in later years become a famed and respected motion picture actor. Of Mr. Nagel the reviewer said only, "Conrad Nagel appears again this week as the Indian catcher of the team." ${ }^{23}$ Nagel's work at the Princess, unlike that of other Company members, was sporadic and inconsistent, with his name turning up on the playbill about once every five weeks during the season. This was due to the fact that he was a college student at Hiland Park College and not a full time member of the Company.

Two weeks later, the Des Moines Register and Leader reviewer made the following statement about Fay Bainter's portrayal of Anne Lester in The Only Son, a play by Winchell Smith: 
Miss Bainter appears this week in a more subordinated part than any she has had thus far. She is the girl whom the son has always loved and who falls in love with him when she discovers his more solid nature. But even in the minor role, a gesture or an expression gives a distinguishing mark to her work. $^{24}$

It may not seem that the reviewer was all that excited about Miss Bainter's performance, but these few lines of praise represented a big turning point in her Des Moines career. This was the first time that Des Moines' reviewers had given more attention to Bainter than to Margaret Dills, the Company's leading lady, who received only a passing mention. Also important is that for the first time reviewers were beginning to notice a very distinct style in Fay Bainter's acting. She was obviously a polished actress even at this early stage, but what seemed to fascinate the reviewers even more was her use of facial expressions and gestures. These qualities in her acting style were mentioned again a week later when she played Mollie Wood in The Virginian, a play by Owen Wister. A reviewer stated:

. . Miss Bainter, too, was a charming Mollie Wood and played the role with innumerable delightful little gestures and expressions, which Princess regulars have come to expect. ${ }^{25}$

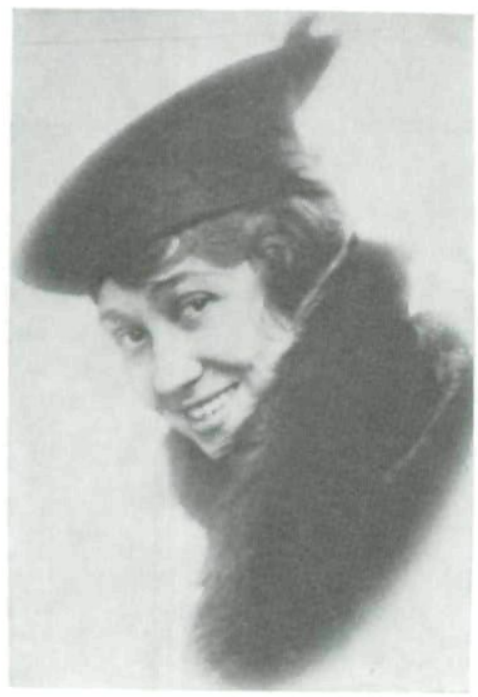

Fay Bainter

Certainly Fay Bainter had caught the eye of both the press and public, and there is every possibility that her popularity was due to a new style of acting, or at least a style that Des Moines theatregoers were unfamiliar with. In this writer's opinion she was probably moving away from the stiffer style of acting that was so familiar to the melodrama. That melodramatic period of acting included the grand gestures and retorical voice patterns combined with very stylized and sharp movements on the stage. Fay Bainter, on 
the other hand, was most likely taking advantage of her natural grace in movement and voice. We know from descriptions and pictures of her that she was small and had a very distinct face, in which case the more natural gestures of the body and the slighter expression in the face would be much more noticeable. We are also told in numerous accounts that she possessed a speaking voice of strength and fairly high pitch, making the voice very distinct and expressive at a low volume, which in turn would sound closer to a natural speaking voice than the half shout of many actors of the period. Lastly, she probably showed a great deal of energy on the stage.

At this time in American Theatre, naturalism was the newest trend. However, this trend had probably not reached the midwestern area, and it may have been that Fay Bainter was one of the early practitioners of such a style.

Regardless, by November, Fay Bainter had become one of the most, if not the most, popular member of the Company. Almost weekly there appeared personal items concerning her in the Princess Bulletin. The Bulletin's "Letter Box" was continually flooded with questions about Fay Bainter. The newspapers, too, were generous to her, and she never seemed to be excluded from some mention in the "Plays and Players" page of the Des Moines Register; there were even occasions when she was mentioned on the society pages, something that rarely occurred because of the generally low regard in which most actors were held.

With this sudden burst of popularity it would seem only natural that Miss Bainter would graduate from supporting roles to lead roles, and, on November 29, 1914, she opened in her first lead role as Maggie Pepper in the play Maggie Pepper by Charles Klein. The reviewers raved, with one saying:

The whole play revolves about Maggie and the character has been humanized by Miss Bainter's sincere art. Throughout the performance there are innumerable touches that are due entirely to Miss Bainter and not Mr. Klein, the playwright and these cannot escape the spectator. There are many clever lines, and Miss Bainter in reading them exercises her fine talent for the quiet rendering of sentiment and drollery. ${ }^{26}$

And this review was only the beginning. Later in the season, as Juanita in David Belasco and Richard Tully's The Rose of the Rancho, one reviewer said of Fay Bainter: 
We have said that the plays chief interest is as a spectacle. It does, however, give Miss Bainter another opportunity to show her versatility. She is Junita (sic.) the rose of the rancho. She presented a truly fascinating picture of girlish charm and grace. As the high-spirited, mischievous little Spanish girl, she is in turn roguish, grave, rebellious, submissive, haughty, and tender. Her comedy was natural, spontaneous and wholly delightful. She struck almost every human note, each of which rang true. ${ }^{27}$

By the end of the season Fay Bainter was literally the leading lady of the Princess Stock Company. Margaret Dills, former leading lady, had virtually been dropped in favor of Miss Bainter. Quite obviously Miss Dills didn't care for this turn of events and was not to return to the Company the following year. Likewise, Edward Woodruff, the Company's leading man, found himself in a similar situation. It was implied that he was too old to play opposite the younger Miss Bainter and that a new leading man would have to be found for the next season.

\section{The Second Bainter Year (1915-16)}

In August of 1915 Fay Bainter and the Company began preparing for the season's opening production. Charles Gunn, a fine figure of a man, and much closer to Miss Bainter's age than had been Edward Woodruff, was chosen to become her leading man. With a few minor exceptions the rest of the Company remained the same.

Their opening production of Nearly Married by Edgar Selwyn did not elicit the response the Company had hoped for. Reviews were only fair and the Des Moines. Register and Leader said of their leading lady:

Miss Bainter played the role of the nearly married wife with all her accustomed skill, with all the snap and grace and charm which endeared her to every Des Moines theatregoer last year. ${ }^{28}$

The next week, for the Company's production of The Misleading Lady by Charles Goddard and Paul Dickey, the Company received a review that was even colder. It stated:

The portrayal of the heroine is not one of the best things Miss

Bainter has done. The role is a trying one, not at all sympathetic and in many ways badly drawn, but Miss Bainter does the best she can do with it. One is almost tempted to say that she does the best that can be done with it. She shows throughout a keen appreciation for the humorous possibilities of the part, and that is about all the quality it has. ${ }^{29}$ 
As the season moved on the reviews became cooler and took on the "book report" quality that was so obvious in the years past, and there was a definite sense of politeness in what was said of the productions. The only real value derived from the reviews was the indication that the Company was not doing the quality of work they had done the previous season. It can only be speculated upon as to the reasons. One possibility could have been that Elbert and Getchell had turned a great deal of their attention, and money, to their Berchel Opera House. Another might be due to the increasing age of the Company's director, Priestly Morrison. And a final possibility could have been dissension within the Company as several unannounced changes took place in midseason, including the replacement of Charles Gunn, the leading man, by Robert Hyman.

Neither was Miss Bainter fairing well with the reviewers. Most of them were warm at best and some showed strong signs of sarcasm. The October 18, 1915, review of Her Own Money by Augustus Thomas said of Miss Bainter only that, "The strength of Miss Bainter's work, when the fact of the separation became real, was gripping." ${ }^{\text {"3o }}$ Not exactly the type of review that could be considered earth shaking. And again on October 25, 1915, for her role in All On Account of Eliza, the reviewer for the Register and Leader stated:

Miss Bainter has an opportunity for coquetishness this week. Her rogueries are largely confined to one scene, however, where they are an avowed assumption. . ." ${ }^{31}$

These comments, and others like them, must have greatly upset the Company and forced them to some sort of action. Shortly after this the reviews began to pick up and it is assumed that the qualities of the shows did too.

Fay Bainter and the Company made their big comeback with a mid-season revival of David Belasco's Girl of the Golden West. This play had previously been produced twice by the Company, the first time in 1910 and again in 1913. The reason for this third revival was due to a "polling" of Princess audiences in late September and early October, when reviews and attendance seemed to have been at their worst. It was to be an all new production, and Sam Wohl, the Master Mechanic, had been working for three weeks prior to the opening pre- 
paring all new scenery. (Scenery for the 1913 production was the same as that built for the production of 1910). Likewise, Mary Brooks, the Wardrobe Mistress, was busy building new costumes for the show, and A. O. Sterling, Properties Master, was collecting and arranging new properties and stage furnishings. This must have been exciting for the patrons of the Princess as scenery was generally reused many times, and seldom did a production have all new scenery, costumes, and properties.

There was a sense of excitement in Des Moines prior to the opening week of Girl of the Golden West. It was one of the most popular shows of the turn of the century and considered a real crowd pleaser. Its popularity can easily be attested to by an article published in The Des Moines News on opening day, which read:

'The Girl of the Golden West,' a Belasco play, will be revived today by Elbert and Getchell at the Princess Theater, where it was last seen in March of 1913. At a recent play-voting contest at the Princess, 'The Girl of the Golden West' received the largest number of votes,

The production will be made with entirely new scenery and Mr. Hyman will appear in the same role he enacted at the last revival, that of Dick Johnson, the 'road agent,' and Miss Bainter will be seen for the first time as Minnie Smith, the girl around whom the interest of the play centers. ${ }^{32}$

The other Des Moines newspapers were equally enthusiastic and all carried feature stories about the show, and all sent reviewers to either the Sunday matinee or Sunday evening performance.

The production was a great success. The reviewers liked the show and loved Fay Bainter as Minnie. The reviewer for the Des Moines Register and Leader, in very flowery language, described her performance, saying:

Interest, of course, centered in the girl. Miss Bainter gave a performance of extraordinary strength and variety ... The exaction is tremendous, equally upon physical resources and nervous vitality, but at almost every point it was met and satisfied. ${ }^{33}$

Neither were the other members of the journalistic community unkind or ungenerous to the production. The Des Moines News, reviewer, in the Monday edition, said of the show:

The play is well staged. Mr. Forstelle, as the sheriff particularly was pleasing. Mr. Young did well as Sanora Slim. Mr. 


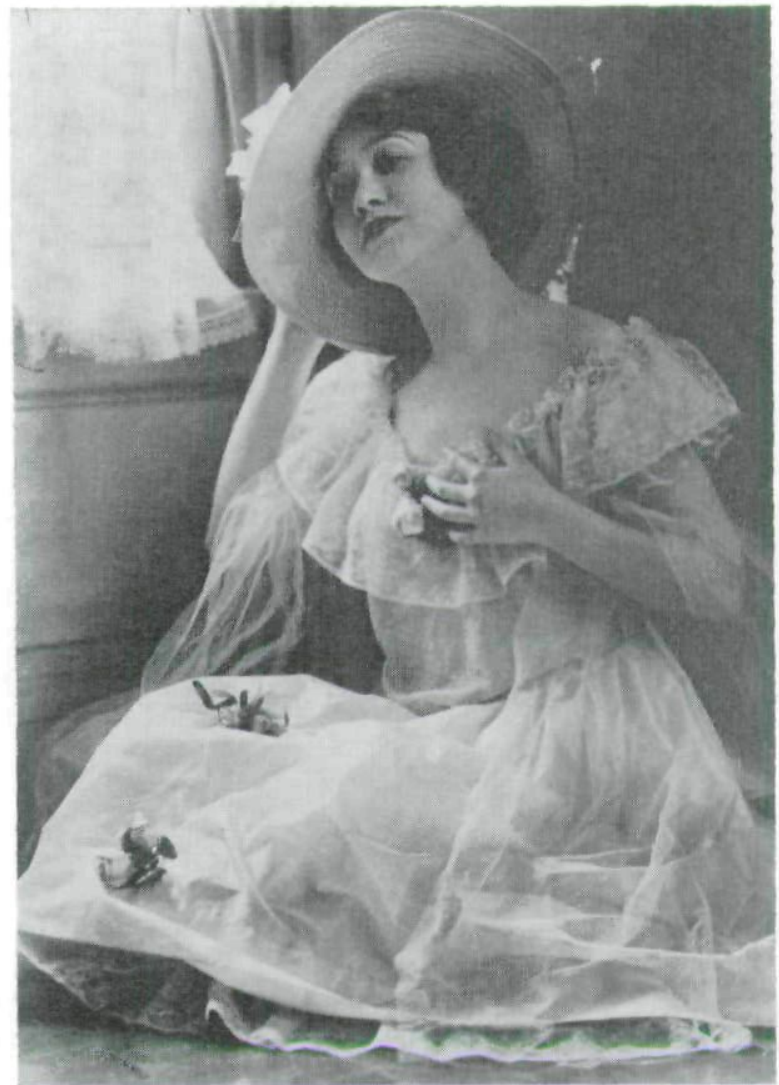

Fay Bainter

Hyman as Ramarez was convincing at times. Mrs. Morrison played the part of the Indian squaw. Robert Brister was Nick the Bartender. Opinion-very good show. ${ }^{34}$

And finally, from the Monday edition of the Des Moines Capital came these very complimentary comments:

The opening tableau, where a panoramic view of Cloudy Mountain with the Polka saloon at the foot is unfolded by means of a painted canvas, is beautiful.

As the 'girl' Miss Bainter is called upon to present a difficult role. The slangy barmaid is required to 'register' love, hatred, sorrow and all the other emotions of woman, but in a manner different from the ordinary kind. Miss Bainter swears admirably, mixes drinks deftly and expresses scorn and derision forcibly. Her moments of deep affection are a little too much 
on the drawing room order for a girl who has lived her life in a saloon, however.

Mr. Hyman as the road agent strengthens his work by a careful reserve where it is needed and a forceful reading of his lines in the more tense moments. Mr. Forstelle looks and acts the part of Jack Rance, the sheriff, admirably. Mr. Young as Sonora Slim and Mr. Brister as Nick, the bartender, are both good. Mrs. Morrison, the only other woman in the cast, handles the part of the squaw maid with credit. ${ }^{35}$

Once again Fay Bainter and the Company were back in the good stead of the public and the press, and they stayed there for the remainder of the season, which was relatively uneventful until the middle of February when Fay Bainter fell ill, having a fainting spell during a performance. The following week the Princess Bulletin announced that Kitty Brown, a leading lady who had most recently been working for Charles Frohman, a large eastern theater owner, would replace Miss Bainter during her illness. The announcement said of Fay Bainter:

Her physician announced that she was suffering from extreme

fatigue, due to her exacting work in playing the many arduous leading roles in the plays produced this season, and that it would be necessary for Miss Bainter to seek absolute rest and quiet, in order to restore her vitality to a normal condition. ${ }^{36}$

Miss Bainter recovered her health quickly and soon reassumed her place in the Company as "the darling of Des Moines." This, however, was short lived, and within two weeks of her recovery she announced that this would be her last season with the Princess Stock Company, and that she wanted to go east and work in New York.

During the week of the season's farewell performances, Priestly Morrison, aging rapidly and showing signs of fatigue from the long season, spoke to the audience, saying, "What we have done here is good. We, here at the Princess, feel that we have achieved the highest standards of theatre excellence, and what we have had may never be again."

The Years After Fay Bainter (1916-30)

As in the years past, Priestly Morrison returned to Des Moines from California, where he spent his summers, to begin a new season at the Princess Theater. Many of the old Company members who had been with him in the past were back for the season. Robert Hyman was still the leading man of the 
Company, and Florence Ritterhouse, a west coast actress, had been signed to replace Fay Bainter as the Company's leading lady.

The season opened on August 20, 1916, with a production of Under Cover by Roi Megrue. The show was well done and met with favorable reviews and good public acceptance. However, all was not well within the Company. Morrison was beginning to feel his age, being at this time in his sixties, and it appears as though he was having problems handling the Company. There appears to have been a general revolt of the Company, for reasons unknown, in December of 1916. Without notice Florence Ritterhouse was replaced by Elsie Rizer as the Company's leading lady, and, at the same time, Robert Hyman was replaced as leading man by Albert Phillips, who in turn was replaced less than a month later. With the new year came the announcements of more replacements, filling vacancies held for several seasons by substantial performers.

The final blow, however, came in March of 1917 when it was announced that Morrison was ill and that he would be codirecting the next few productions with William J. Mack, an actor and assistant director who had been with the Company

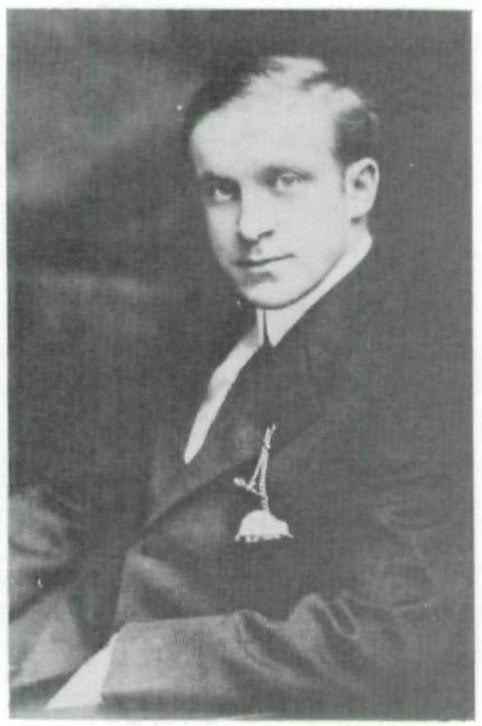

William J. Mack 
since 1911. The next two productions of the season were directed on that basis, but then the two productions following were directed exclusively by Mack. Morrison was able to return to the directorship and finish out the season, but it was announced in the last issue of the spring Bulletin that he had decided not to return for the next season.

The beginning of the 1917-18 season found William J. Mack as director of the Company. Some of the Company members from the previous season were still present, but many new faces were to be seen. The opening production received warm but guarded reviews.

The Company did not seem to be doing well. More and more commercial advertising appeared in the Bulletin, and the trend of the newspapers seemed to give more attention than ever before to the motion picture, which at this time was probably taking a real toll on the Princess' attendance. The Company did, however, make it through the season, but with little success.

From the end of the 1917-18 season the Princess Theater was in trouble. Attendance was never good. There were many changes in Company personnel, and the motion picture, now better than in the past, was drawing public attention away. During the 1918-19 season William J. Mack was replaced by Fredrick Sullivan, who had been the Company's first director, only to be replaced by Mack during the 1919-20 season. Leading men and women changed several times and there were so many turnovers in the Company personnel that it was impossible to keep track of them all.

There was also a change of management. In 1920 Elbert and Getchell gave up their lease on the Princess, and for the next two years it was controlled by the Adams Theaters Company with Mack as director. Then again in 1922 Elbert and Getchell, with Earl Lee as director, acquired control, only to let the Princess go again in 1925.

Morgan Wallace, a producer and playwright, gained control of the Princess for the 1925-26 season. He was completely unsuccessful and lost control at the end of only one season.

Then, in 1926 the Princess was leased by Ralph Bellamy, later to become one of America's outstanding stage and screen 
actors, and the Company was renamed "The Ralph Bellamy Players," with Walter Gilbert as director.

Bellamy was ambitious and wanted to make the theater a success, but every indication would seem to be that he went into the venture without the necessary financial resources. Immediately upon opening he made the following appeal to the general public:

In making our first week's appearance to you, good people of Des Moines, we, the Ralph Bellamy Players, bid for your acceptance of us as your very own company.

... It is too much to assume, that you have already helped to produce some present day stars of the stage and may help to bring forth more by your friendly, understanding, appreciativeness? To do their best work, actors and actresses must positively have the audience 'with them.' Let's be friends. We'll do our part. $^{38}$

Bellamy's Company was in trouble from the beginning, and they seemed to know it. It is a good possibility that the initial expense of taking over the theater and forming a company was much greater than had been anticipated. Further, from the beginning of the season, the Princess Bulletin was crammed so full of commercial advertising that there was room for only house notices and casts' lists.

The season opened on September 12, 1926, almost a month later than the theater had ever opened before, with a production of Seventh Heaven by Austin Strong. The Bulletin indicates that attendance of the production was good. This condition, however, was short lived, and within a few weeks attendance was down. The Company was probably on the verge of financial collapse. They became so desperate that they began asking organizations and clubs to sell their tickets, and began giving over the theater three nights a week for theatre parties. In October the following announcement appeared in the Bulletin:

You have the opportunity of making considerable money by taking over the sale of seats for this theater on Monday and Tuesday nights. For example, the Immaculata Club has Monday, Oct. 18th, and several other ogranizations are now arranging dates. It is a sure profit-maker for any live group, and there is no risk. Phone the management. Walnut $5062{ }^{39}$

There is very little documentation to indicate how the season progressed. The newspapers during this time had vir- 
tually lost interest in the theatre and used most of their time and space reviewing the latest motion picture. The Bellamy Players never received more than passing mention.

Bellamy was, however, able to finish the season, with one of the Company's last shows being a production of Maxwell Anderson's What Price Glory, which was done as a benefit for the Argonne Post of the American Legion, of Des Moines. At the end of the season Bellamy let his lease on the Princess lapse.

The following year William C. Walsh took over the Princess and formed a new company. He had good financial backing and was able to last two full seasons, but in the end, he too failed. The motion picture had by this time completely swept the audiences away from the legitimate theatre, and the radio, just then coming into its own, was keeping many people at home.

After the Walsh Company failed, the old Princess sat idle for almost a year. Then, in the spring of 1930, Oscar Lofquist, the original owner of the theater, sold it to the Des Moines Moose Lodge. The Princess which had for almost a generation housed the finest stock companies the State would ever see stood until 1968 when it was sold and razed for a parking lot.

\section{NOTES}

${ }^{1}$ Julius Cahn's Official Theatrical Guide, Iowa Theatre Collections, Iowa State Historical Library, Des Moines, 1908-09, pp. 412-37.

${ }^{2}$ The Princess Theater Bulletin, 1 Nov. 1909, pp. 2-3.

${ }^{3}$ Ibid.

${ }^{4}$ Ibid.

${ }^{5}$ Ibid.

${ }^{6}$ Theatrical Review, The Des Moines Register and Leader, 2 Nov. 1909 , p. 8.

${ }^{7}$ Ibid.

${ }^{8}$ Ibid.

'Tbid.

${ }^{10}$ Theatrical Review, The Des Moines Daily Capital, 2 Nov. 1909, p. 6.

${ }^{11}$ Ibid.

${ }^{12}$ Ibid.

${ }^{13}$ Theatrical Review, The Evening Tribune, 2 Nov. 1909, p. 5.

${ }^{14}$ Editorial, The Des Moines Daily News, 2 Nov. 1909, p. 3.

${ }^{15}$ The Princess Theater Bulletin, 2 May 1910, p. 2.

${ }^{16}$ Ibid.

${ }^{17}$ Ibid., 20 Nov. 1910, p. 3.

${ }^{18}$ Ibid., 18 Dec. 1910, p. 1. 
19"Plays and Players," The Des Moines Sunday Register, 21 May 1911, p. 44.

${ }^{20}$ Ibid., 8 Oct. 1911 , p. 4.

${ }^{21}$ Ibid., 7 Sept. 1913, p. 4.

${ }^{22}$ The Des Moines Register and Leader, 7 Sept. 1914, p. 9.

${ }^{23}$ Ibid.

${ }^{24}$ The Des Moines Register and Leader, 28 Sept. 1914, p. 9.

${ }^{25}$ Ibid., 12 Oct. 1914, p. 7.

${ }^{26}$ Ibid., 30 Nov. 1914, p. 8 .

${ }^{27}$ Ibid., 18 Jan. 1915, p. 8.

${ }^{28}$ Ibid., 23 Aug. 1915, p. 10.

${ }^{29}$ Ibid., 30 Aug. 1915, p. 8.

${ }^{30}$ Ibid., 18 Oct. 1915 , p. 7.

${ }^{31}$ Ibid., 25 Oct. 1915 , p. 9.

${ }^{32}$ "Stories and Notes of Photo Plays and the Theatre," The Des Moines News, 28 Nov. 1915, p. 12.

${ }^{33}$ The Des Moines Register and Leader, 29 Nov. 1915, p. 6.

${ }^{34}$ The Des Moines News, 29 Nov. 1915, p. 3.

${ }^{35}$ The Des Moines Daily Capital, 29 Nov. 1915, p. 5.

${ }^{36}$ The Princess Theater Bulletin, 13 Feb. 1916, p. 1.

37"Plays and Players," The Des Moines Sunday Register, 28 May 1916, p. 44.

${ }^{38}$ The Princes Theater Bulletin, 12 Sept. 1926, p. 2.

${ }^{39}$ Ibid., 3 Oct. 1926, p. 3.

\section{Works Consulted}

The Princess Theater Bulletins, Celia Coggswell Theatre Collections, Iowa State Historical Library, Des Moines, 1909-29.

Julius Cahn's Official Theatrical Guide, Iowa Theatre Collections, Iowa

State Historical Library, Des Moines, 1908-09.

The Des Moines Sunday Register, Des Moines, 1909-27.

The Des Moines Register and Leader, Des Moines, 1909-19.

The Des Moines Daily Capital, Des Moines, 1909-18.

The Evening Tribune, Des Moines, 1909-18.

The Des Moines News, Des Moines, 1909-18.

\section{Early Iowa and Copperhead Journalism}

\section{By David L. Lendt}

Mr. Lendt has been assistant to the vice-president for information and development at Iowa State University since 1967. He received his B.S. degree in technical journalism from Iowa State in 1960 and his M.A. degree in history in 1971. The following article is based upon research which Mr. Lendt did for his book-length thesis, Demise of the Democracy: The Copperhead Press in Iowa. Mr. Lendt is also presently pursuing further graduate work in the College of Education at Iowa State.

In more than a century's study of its causes and results, 
Copyright of Annals of Iowa is the property of State of Iowa, by \& through the State Historical Society of Iowa and its content may not be copied or emailed to multiple sites or posted to a listserv without the copyright holder's express written permission. However, users may print, download, or email articles for individual use. 